\title{
Identifikasi Hambatan Belajar Mahasiswa Universitas Sriwijaya Pada Masa Pandemi Covid-19
}

\author{
Rani Mega Putri ${ }^{*}$, Rahmi Sofah ${ }^{2}$, Silvia AR $^{3}$, Ilham Arvan Junaidi ${ }^{4}$ \\ ${ }^{1 * 2,3}$ Program Studi Bimbingan dan Konseling FKIP Universitas Sriwijaya, \\ ${ }^{4}$ FKIP Universitas PGRI Palembang \\ *Corresponding Author. Email: rani@konselor.org
}

\begin{abstract}
This study aims to identify learning barriers of Sriwijaya University students during the Covid-19 pandemic. The method used in this research was a survey. The subjects in this study were students of the Guidance and Counseling Study Program, Sriwijaya University. The data collection technique used a questionnaire instrument that was distributed to respondents online using a google form. The results of the study showed that the learning barriers of Sriwijaya University students on internal factors amounted to $56.58 \%$, while on external factors amounted to $55.12 \%$. So, it can be concluded that the two factors of learning barriers are in the medium category.
\end{abstract}

\begin{abstract}
Abstrak: Tujuan dalam penelitian ini adalah untuk mengidentifikasi hambatan belajar mahasiswa Universitas Sriwijaya pada masa pandemi Covid-19. Metode yang digunakan dalam penelitian ini adalah survei. Subjek dalam penelitian ini adalah mahasiswa Program Studi Bimbingan dan Konseling Universitas Sriwijaya. Teknik pengumpulan data menggunakan menggunakan instrumen angket yang disebarkan kepada responden secara online menggunakan google form. Hasil penelitian ini menunjukan bahwa hambatan belajar mahasiswa Universitas Sriwijaya pada faktor internal sebesar $56.58 \%$, sedangkan pada faktor internal sebesar $55.12 \%$, sehingga dapat disimpulkan bahwa kedua faktor hambatan belajar tersebut berada pada kategori sedang.
\end{abstract}

\section{Article History}

Received: $15-03-2021$

Revised: 07-05-2021

Accepted: 29-07-2021

Published: 07-09-2021

\section{Key Words:}

Learning Barries, Student, Covid-19.

\section{Sejarah Artikel}

Diterima: 15-03-2021

Direvisi: 07-05-2021

Disetujui: 29-07-2021

Diterbitkan: 07-09-2021

\section{Kata Kunci:}

Hambatan Belajar, Mahasiswa, Covid-19.

How to Cite: Putri, R., Sofah, R., AR, S., \& Junaidi, I. (2021). Identifikasi Hambatan Belajar Mahasiswa Universitas Sriwijaya Pada Masa Pandemi Covid-19. Jurnal Kependidikan: Jurnal Hasil Penelitian dan Kajian Kepustakaan di Bidang Pendidikan, Pengajaran dan Pembelajaran, 7(3), 692-698. doi:https://doi.org/10.33394/jk.v7i3.3574

https://doi.org/10.33394/jk.v7i3.3574

This is an open-access article under the CC-BY-SA License.

\section{Pendahuluan}

Setiap manusia di dalam kehidupan selalu menemui masalah dari setiap aktifitas serta pekerjaan berupa tuntutan dan tekanan untuk mencapai tujuan, tekanan tersebut dapat berasal dari lingkungan bahkan diri sendiri. Menetapkan pilihan menjadi mahasiswa merupakan salah pilihan dengan tujuan ingin perubahan besar dalam perkembangan masa remaja yang menjadi tekanan dalam kehidupan seseorang. Mahasiswa adalah kelompok masyarakat yang status terikat dengan Perguruan Tinggi dengan harapan dapat berperan dalam memberikan kotribusi pada masyarakat (Hurlock, 2003).

Peralihan dari Sekolah Menengah Atas (SMA) ke Perguruan Tinggi (PT) berpotensi terbentuknya sebuah kendala yang dihadapi yaitu hambatan dalam belajar, dikarenakan penyesuaian dengan lingkungan yang baru serta tingkatan materi yang diberikan selama perkuliahan, kendala tersebut berasal dari internal maupun eksternal. Budaya hingga norma yang baru ditemui, komunitas mayarakat yang baru, memampuan dalam penyesuaian diri pada lingkungan sosial, gaya hidup tentunya menuntut waktu dan pengendalian diri yang 
berbeda pada saat sekolah, hingga tidak sedikit mahasiswa yang harus meninggalkan keluarga untuk mencapai sebuah tujuan dalam belajar, tugas perkuliahan serta jadwal perkuliahan yang padat menyebabkan timbulnya permasalah hingga tekanan pada diri mahasiswa (Hasanah et al., 2020).

Mewabahnya Coronavirus Disease 2019 (Covid-19) turut menyumbangkan masalah dalam pembelajaran, tidak terkecuali bagi mahasiswa. Banyak permasalahan baru yang dapat menjadi hambatan bagi mahasiswa dalam belajar seperti kecakapan menggunakan komputer dan internet, jaringan internet, beban biaya internet serta kemampuan dosen dalam menyampaikan materi pembelajaran kepada mahasiswa. Hasil penelitian Jamaluddin, dkk (2020) menunjukkan bahwa kendala yang sering dihadapi mahasiswa berupa jaringan internet yang tidak stabil (23\%) dan kuota internet yang terbatas $(21 \%)$ merupakan faktor dominan yang menghambat pelaksanaan proses pembelajaran daring. Apabila tidak menjadi perhatian tentunya kendala ini juga akan berdampak pada kondisi psikis responden (>90\%), tetapi untuk $72 \%$ responden menggunakan aktivitas lain untuk mengatasi gangguan tersebut. Selanjutnya penelitian Hasanah, dkk (2020) menjelaskan bahwa aktivitas belajar daring mahasiswa pada masa pandemi Covid-19 dengan kebijakan belajar dari rumah "cukup baik". Berdasarkan situasi force majeure hingga segala tantangan dan hambatan yang ada diharapkan dapat dijadikan sebagai bahan evaluasi berdasarkan pengalaman pembelajaran daring mahasiswa maupun dosen.

Hambatan maupun kesulitan belajar adalah gejala yang dapat diamati dan di identifikasi pada mahasiswa baik berdasarkan perilaku ataupun prestasi belajarnya (Anugrahana, 2020; Yuwono, 2020). Berdasarkan hasil observasi dan wawancara yang dilakukan pada masa pandemi Covid-19 dengan mahasiswa Program Studi Bimbingan dan Konseling Universitas Sriwijaya, ditemui mahasiswa yang merasa bahwa dirinya memiliki hambatan belajar, gejala tersebut dirasakan berupa penurunan motivasi, tidak percaya diri dalam mengikuti beberapa matakuliah yang diikuti, hingga menghindari mengikuti perkuliahan bahkan tidak konsentrasi dan antusias dalam mengikuti perkuliahan, sehingga tidak memahami apa yang telah diajarkan dosen. Selain itu, berdasarkan wawancara yang dilakukan saat masa pandemi Covid-19 kepada beberapa orang mahasiswa bimbingan dan konseling, didapat informasi bahwa mahasiswa kesulitan dalam menguasai materi karena keterbatasan jaringan internet di tempat tinggalnya, kesulitan memahami penjelasan dosen, serta perasaan cemas terkait dengan pandemi yang sedang terjadi.

Hambatan merupakan halangan berupa rintangan maupun suatu situasi yang tidak diinginkan atau disukai, dapat mengganggu perkembangan psikis maupun psikologis seseorang, dapat menyebabkan kesulitan baik pada diri sendiri maupun orang lain serta perlu untuk dihilangkan (Arifa, 2020; Sari et al., 2017). Kesulitan yang muncul tentunya mengganggu rangkaian perkembangan belajar (Syah, 2010). Kesulitan belajar merupakan kondisi dan situasi berupa anak didik tidak mampu belajar secara normal dan wajar, yang disebabkan adanya gangguan, ancaman, serta hambatan selama proses belajar mengajar. Kesulitan belajar juga merupakan situasi kesukaran yang dihadapi individu pada saat menerima maupun menyerap materi pelajaran. Kesulitan belajar juga merupakan suatu situasi yang dapat menyebabkan individu tidak mampu dapat belajar sebagaimana biasanya (Dalyono dalam Riyanti, 2015).

Bagi mahasiswa yang mengalami kesulitan dalam belajar yang merupakan termasuk dalam hambatan belajar akan sukar dalam menyerap materi pelajaran yang telah disampaikan oleh dosen, tidak mengerjakan tugas yang disebabkan malas dalam belajar dan mengikuti perkuliahan, dikarenakan perasaan tidak dapat menguasai materi. Dengan begitu mahasiswa selama melaksanakan perkuliahan cenderung tidak fokus, tidak bergairah, sehingga 
mengabaikan tugas yang diberikan, nantinya akan bermuara pada turunnya prestasi belajar mahasiswa.

Menurut Syah (2010), pernyebab munculnya hambatan belajar disebabkan oleh faktor internal dan faktor eksternal. Faktor internal adalah keadaan disebakan dari dalam diri mahasiswa itu sendiri. Faktor eksternal merupakan keadaan yang terjadi disebakan luar diri individu. Setiap hal yang timbul secara eksternal mupun internal ini harus segera diatasi, agar permasalahn itu tidak berlarut-larut dan memberikan dampak negatif bagi prestasi belajar.

Berdasarkan tekanan yang terjadi pada mahasiswa, dosen dituntut untuk dapat menyusun suatu strategi penyelesaian masalah. Strategi yang dilakukan akan berbeda tergantung dari masalah yang dihadapi. Mahasiwa juga harus mampu mengidentifikasi bagaimana permasalah yang dihadapi secara berkala. Adapan tujuan penelitian ini adalah untuk mengidentifikasi hambatan belajar mahasiswa Universitas Sriwijaya pada masa pandemi Covid-19. Penelitian ini sangat penting untuk dilakukan secara berkala kepada mahasiswa dikarenakan khusunya pada saat pembelajaran jarak jauh pada masa pandemi Covid-19 ini. Seorang dosen harus mampu mengidentifikasi dan menganalisis penyebab adanya hambatan belajar dalam kelas yang diajarkannya, untuk dicarikan solusi dari permasalahan yang dihadapi oleh mahasiswa.

\section{Metode Penelitian}

Penelitian ini menggunakan pendekatan kuantitatif dengan metode survei (Sugiyono, 2014). Penelitian ini dilakukan pada mahasiswa Program Studi Bimbingan dan Konseling Universitas Sriwijaya yang berjumlah 111 orang, penarikan sampel menggunakan teknik total sampling. Pengumpulan data pada penelitian ini menggunakan angket hambatan belajar dengan skala pengukuran model Likert, Skala Likert ini digunakan untuk mengukur hambatan belajar dengan alternatif jawaban dengan bobot nilai 1,2,3,4, dan 5. Bentuk dari jawaban skala likert adalah sebagai berikut:

Tabel 1. Skor Skala Likert untuk Inventori Hambatan Belajar

\begin{tabular}{lcc}
\hline Alternatif Jawaban & Skor Favourable & Skor Unfavourable \\
\hline SL = Selalu & 1 & 5 \\
SR = Sering & 2 & 4 \\
K = Kadang-kadang & 3 & 3 \\
JR = Jarang & 4 & 2 \\
TP = Tidak Pernah & 5 & 1 \\
\hline
\end{tabular}

Sebelum angket tersebut diberikan kepada responden, terlebih dahulu dilakukan uji coba instrumen baik itu validitas maupun reliabilitas. Analisis data menggunakan deskriptif kuantitatif (persentase). Hasil skor dari pegolahan data tersebut diinterpretasikan berdasarkan table berikut:

Tabel 2. Kriteria Interpretasi Hasil Analisis Data

\begin{tabular}{cll}
\hline No & \multicolumn{1}{c}{ Kategori } & \multicolumn{1}{c}{ Persentase } \\
\hline 1 & Sangat Tinggi & $0 \%-20 \%$ \\
2 & Tinggi & $21 \%-40 \%$ \\
3 & Sedang & $41 \%-60 \%$ \\
4 & Rendah & $61 \%-80 \%$ \\
5 & Sangat Rendah & $81 \%-100 \%$ \\
\hline
\end{tabular}

Sumber: (Sudjiono, 2007) 


\section{Hasil Penelitian dan Pembahasan}

Berdasarkan dari hasil penelitian yang dilaksanakan terhadap 111 responden penelitian yang dilakukan pada kedua indikator tentang hambatan belajar baik internal maupun eksternal menggunakan angket hambatan belajar yang disebarkan secara online melalui bantuan google form, sebelum instrumen disebarkan telah dilakukan uji coba instrumen dengan kesimpulan seluruh butir pernyataan valid dan reliabel. Pada bagian ini akan disajikan rangkuman kesuluruhan hasil penelitian, dari hasil penelitian tersebut dapat dijelaskan sebagai berikut:

Tabel 3. Deskripsi Hasil Penelitian

\begin{tabular}{|c|c|c|c|c|c|c|}
\hline No & Indikator & Aspek & $\begin{array}{c}\text { Capaian } \\
\text { Indikator }\end{array}$ & $\begin{array}{c}\text { Keterangan } \\
\text { Indikator }\end{array}$ & $\begin{array}{c}\text { Capaian } \\
\text { Aspek }\end{array}$ & $\begin{array}{c}\text { Keterangan } \\
\text { Aspek }\end{array}$ \\
\hline \multirow[t]{3}{*}{1} & Internal & Faktor Jasmani & $56.58 \%$ & Sedang & $50.50 \%$ & Sedang \\
\hline & & Faktor Psikologis & & & $48.93 \%$ & Sedang \\
\hline & & Faktor Kelelahan & & & $68.47 \%$ & Tinggi \\
\hline \multirow[t]{4}{*}{2} & Eksternal & Faktor Keluarga & $55.12 \%$ & Sedang & $50.70 \%$ & Sedang \\
\hline & & $\begin{array}{l}\text { Faktor Perguruan } \\
\text { Tinooi }\end{array}$ & & & $60.68 \%$ & Tinggi \\
\hline & & $\begin{array}{l}\text { Faktor Lingkungan } \\
\text { Masyarakat }\end{array}$ & & & $55.09 \%$ & Sedang \\
\hline & Kes & luruhan & & & $55.85 \%$ & Sedang \\
\hline
\end{tabular}

Hasil penelitian pada variabel hambatan belajar mahasiswa Program Studi Bimbingan dan Konseling menunjukkan persentase $55.85 \%$. Hal ini memiliki makna bahwa mahasiswa Bimbingan dan Konseling memiliki hambatan belajar pada kategori sedang. Hambatan yang dimaksud terbagi dalam 2 indikator. Kedua indikator tersebut berada pada kategori sedang. Pada indikator Faktor Internal hambatan tertinggi berada pada aspek faktor kelelahan dengan kategori tinggi sebesar $68,47 \%$. Hal ini disebabkan karena pada masa pandemi mahasiswa secara tiba-tiba diminta merubah metode belajar dari luring menjadi daring. (Pawicara \& Conilie, 2020) menyebutkan bahwa ketidaksiapan mahasiswa menghadapi pembelajaran yang sepenuhnya dilakukan secara daring membuat mahasiswa merasa lelah. Rasa bosan yang dihadapi mahasiwa selama proses perkuliahan daring disebabkan oleh metode yang digunakan terlalu monoton, intensitas dosen dan mahasiswa yang kurang bervariasi, dan berinteraksi secara langsung dengan teman dan dosen tidak dimungkinkan. Rasa bosan dapat berpengaruh terhadap prestasi belajar, sehingga mahasiswa merasa lelah setiap kali harus belajar secara online (Abuhammad, 2020; Ciroma, 2014; Lassoued et al., 2020; Muilenburg \& Berge, 2005).

Faktor internal yang kedua adalah aspek faktor jasmani dengan kategori sedang sebesar 50,50\%. Kondisi fisik/jasmani yang baik tentunya akan berpengaruh terhadap kesiapan mahasiswa dalam belajar. Mata minus dapat menjadi hambatan bagi mahasiswa selama pembelajaran daring. Hal ini disebabkan karena mahasiswa harus berada di depan perangkat komputernya selama berjam-jam untuk belajar. Postur tulang punggung yang kurang baik juga menjadi kendala, karena mahasiswa lebih banyak duduk memperhatikan komputernya.

Pada aspek faktor psikologis dapat disimpulkan hasil analisis data tersebut berada pada kategori sedang dengan persentase sebesar 48,93\%. Hasil penelitian diperkuat dengan hasil penelitian (Oktawirawan, 2020) yang menunjukkan kecemasan mahasiswa dalam belajar daring berdasarkan pemahaman terhadap materi yang kurang, hingga waktu 
pengerjaan tugas yang singkat. Kurangnya memampuan menguasai materi mengakibatkan mahasiswa menemukan kesulitan dalam mengerjakan tugas yang sudah diberikan. Hal tersebut dapat menyebabkan kecemasan bagi mahasiswa yang mengakibatkan terjadinya penurunan nilai ujian hingga ketidaksiapannya dalam menghadapi tingkat materi selanjutnya. Kecemasan ini tentunya hanya merupakan salah satu dari hambatan belajar pada aspek psikologis. Senada dengan itu (Moh, 2020) menjelaskan bahwa masalah yang dihadapi pada masa pandemi Covid-19 ini adalah tuntutan yang harus segera di atasi oleh dosen dengan menerapkan model belajar mengajar secara daring yang menarik dan atraktif.

Proses belajar dengan menerapkan media online mempunya dampak negatif tentunya yaitu melelahkan hingga membosankan, karena tidak terjadinya interaksi langsung antara dosen maupun teman lainnya (Anugrahana, 2020; Becker et al., 2013; Lassoued et al., 2020; Sari et al., 2017). Dengan demikian mengakibatkan frustrasi bagi mahasiswa, apabila permasalahan ini terus berlanjut dapat menimbulkan gangguan lebih serius seperti stress. Hal lain pada aspek psikologis yang dapat menjadi hambatan belajar adalah kesiapan. Luring maupun daring, mahasiswa dituntut untuk siap dalam menerima pelajaran. Ada beberapa hal yang marus menjadi perhatian supaya pembelajaran daring lebih optimal yaitu mengenai kesiapan belajar diantaranya adalah menumbuhan kepercayaan diri mahasiswa terhadap penggunaan perangkat pendukung pembelajaran daring, belajar secara mandiri, pengendalian diri mahasiswa, menjaga motivasi untuk belajar, dan kepercayaan diri dalam menjalin komunikasi secara online (Christiana, 2020; Fitriyani et al., 2020; Rosali, 2020).

Sedikit berbeda dengan pendapat sebelumnya, hasil penelitian (Sadikin \& Hamidah, 2020) menunjukkan bahwa juga terdapat mahasiswa yang merasa nyaman dalam mengemukakan gagasan, pendapat, dan pertanyaan dalam pembelajaran daring. Pembelajaran yang dilakukan dari rumah membuat mereka tidak merasakan adanya tekanan psikologis dari teman seperti ketika mengikuti pembelajaran tatap muka. Tidak adanya kontak langsung antara dosen dengan mahasiswa, membuat mahasiswa merasa tidak canggung dan lebih terbuka dalam menyampaikan gagasan. Ketiadaan penghambat keadaan fisik hingga batasan ruang dan waktu mengakibatkan peserta didik lebih nyaman dalam melakukan komunikasi dan interkasi belajarn mengajar.

Hasil penelitian berdasarkan indikator eksternal, didapatkan hasil bahwa mahasiswa berada tingkat sedang dengan persentase yaitu 55,12\%. Hambatan paling tinggi berada pada aspek faktor Perguruan tinggi pada kategorisasi tinggi dengan persentase sebesar 60,68\%. Hal ini dapat dipengaruhi oleh interaksi antara dosen dan mahasiswa dalam perkuliahan. Senada dengan hasil yang dapatkan, hasil penelitian (Arifa, 2020; Sadikin \& Hamidah, 2020) menunjukkan bahwa masih terdapat mahasiwa yang kesulitan pada saat memahami isi materi perkuliahan yang disampaikan secara daring. Bahan ajar yang biasanya disampaikan dalam bentuk buku bacaan yang tidak mudah dipahami secara menyeluruh oleh mahasiswa secara mandiri.

Selanjutnya aspek faktor lingkungan masyarakat berada pada kategori sedang dengan persentase 55,09\%. Dukungan masyarakat terhadap pembelajaran online yang sedang dijalani oleh mahasiswa tentunya dapat meningkatkan kualitas belajar. Lingkungan masyarakat yang cenderung ribut dan bising dapat membuat mahasiswa tidak berkonsentrasi dalam menjalani pembelajaran daringnya.

Terakhir adalah aspek faktor keluarga berada pada tingkat sedang dengan persentase sebesar $50,70 \%$. Sama halnya seperti lingkungan masyarakat, lingkungan keluarga juga sangat berpengaruh terhadap lancarnya pembelajaran daring. Lingkungan keluarga yang ribut, gangguan di dalam rumah serta kurangnya dukungan oleh anggota keluarga lainnya, sehingga mengakibatkan mahasiswa tidak bisa berkonsentrasi dalam pembelajaran. 


\section{Kesimpulan}

Hasil penelitian ini menunjukkan bahwa hambatan belajar mahasiswa Universitas Sriwijaya pada faktor internal sebesar 56.58\%, sedangkan pada faktor eksternal sebesar $55.12 \%$, sehingga dapat disimpulkan bahwa kedua faktor hambatan belajar tersebut berada pada kategori sedang, hal ini menunjukan bahwa hambatan belajar mahasiswa perlu diperhatikan oleh dosen dalam upaya menjaga produktifitas mahasiwa selama perkuliahan. Hambatan belajar mahasiswa tidak bisa diabaikan oleh dosen, dosen harus mampu mencari dan memecahkan permasalahan tersebut. Dosen dituntut untuk aktif dan kreatif dalam mentransformasikan ilmu kepada mahasiswa, dosen harus mampu menguasai teknologi informasi pada saat sekarang ini. Mahasiswa dan dosen harus bersinergi dan dapat menyesuaikan diri dengan kemajuan teknologi dalam bentuk pembelajaran daring agar tidak jauh tertinggal dan tergerus zaman.

\section{Saran}

Hasil penelitian tersebut dapat dijadikan acuan bagi dosen sebagai bahan pertimbangan agar memperhatikan faktor hambatan belajar mahasiswa sebagai penentu keberhasil proses perkuliahan. Penelitian ini disarankan agar dapat diteliti bukan hanya pada mahasiswa Bimbingan dan Konseling saja, namun juga dilakukan kepada seluruh mahasiswa, agar dapat mengidentifikasi lebih awal kendala yang dihadapi mahasiswa selama proses perkuliahan.

\section{Daftar Pustaka}

Abuhammad, S. (2020). Barriers to distance learning during the COVID-19 outbreak: A qualitative review from parents' perspective. Heliyon, 6(11), e05482. https://doi.org/10.1016/j.heliyon.2020.e05482

Anugrahana, A. (2020). Hambatan, Solusi dan Harapan: Pembelajaran Daring Selama Masa Pandemi Covid-19 Oleh Guru Sekolah Dasar. Scholaria: Jurnal Pendidikan Dan Kebudayaan, 10(3), 282-289. https://doi.org/10.24246/j.js.2020.v10.i3.p282-289

Arifa, F. N. (2020). Tantangan Pelaksanaan Kebijakan Belajar Dari Rumah Dalam Masa Darurat Covid-19. Info Singkat;Kajian Singkat Terhadap Isu Aktual Dan Strategis, XII(7/I), 6. http://berkas.dpr.go.id/puslit/files/info_singkat/Info Singkat-XII-7-I-P3DIApril-2020-1953.pdf

Becker, K., Newton, C., \& Sawang, S. (2013). A learner perspective on barriers to e-learning. Australian Journal of Adult Learning, 53(2), 211-233.

Christiana, E. (2020). Burnout akademik selama pandemi covid 19. Prosiding Seminar Nasional Bimbingan Dan Konseling Mengukuhkan Eksistensi Peran BK Pasca Pandemi Covid-19 Di Berbagai Setting Pendidikan, 8-15. http://pasca.um.ac.id/conferences/index.php/snbk/article/view/1129

Ciroma, Z. I. (2014). Learning Barriers: Challenges and Concerns. Academic Journal of Interdisciplinary Studies, 3(7), 142-145. https://doi.org/10.5901/ajis.2014.v3n7p142

Fitriyani, Y., Fauzi, I., \& Sari, M. Z. (2020). Motivasi Belajar Mahasiswa Pada Pembelajaran Daring Selama Pandemik Covid-19. Jurnal Kependidikan: Jurnal Hasil Penelitian Dan Kajian Kepustakaan Di Bidang Pendidikan, Pengajaran, Dan Pembelajaran, 6(2), 165-175. https://doi.org/10.23917/ppd.v7i1.10973

Hasanah, A., Sri Lestari, A., Rahman, A. Y., \& Danil, Y. I. (2020). Analisis Aktivitas Belajar Daring Mahasiswa Pada Pandemi COVID-19. Karya Tulis Ilmiah (KTI) Masa Work From Home (WFH) Covid-19 UIN Sunan Gunung Djati Bandung Tahun 2020, 4-8. http://digilib.uinsgd.ac.id/id/eprint/30565 
Lassoued, Z., Alhendawi, M., \& Bashitialshaaer, R. (2020). An exploratory study of the obstacles for achieving quality in distance learning during the covid-19 pandemic. Education Sciences, 10(9), 1-13. https://doi.org/10.3390/educsci10090232

Moh, M. (2020). Moh . Muslim: Manajemen Stress pada Masa Pandemi Covid-19 " 193. Jurnal Manajemen Bisnis, 23(2), 192-201.

Muilenburg, L. Y., \& Berge, Z. L. (2005). Students Barriers to Online Learning: A factor analytic study. Distance Education, 26(1), 29-48. https://doi.org/10.1080/01587910500081269

Oktawirawan, D. H. (2020). Faktor Pemicu Kecemasan Siswa dalam Melakukan Pembelajaran Daring di Masa Pandemi Covid-19. Jurnal Ilmiah Universitas Batanghari Jambi, 20(2), 541. https://doi.org/10.33087/jiubj.v20i2.932

Pawicara, R., \& Conilie, M. (2020). Analisis Pembelajaran Daring Terhadap Kejenuhan Belajar Mahasiswa Tadris Biologi Iain Jember di Tengah Pandemi Covid-19. ALVEOLI: Jurnal Pendidikan Biologi, 1(1), 29-38.

Rosali, E. S. (2020). Aktifitas Pembelajaran Daring Pada Masa Pandemi Covid -19 Di. Geography Science Education Journal (GEOSEE), 1(1), 21-30. https://www.researchgate.net/publication/340917125_Kendala_Pelaksanaan_Pembela jaran_Jarak_Jauh_PJJ_dalam_Masa_Pandemi/stats

Sadikin, A., \& Hamidah, A. (2020). Pembelajaran Daring di Tengah Wabah Covid-19. Biodik, 6(2), 109-119. https://doi.org/10.22437/bio.v6i2.9759

Sari, I. P., Purwasih, R., \& Nurjaman, A. (2017). Analisis Hambatan Belajar Mahasiswa Pada Mata Kuliah Program Linear. JIPM (Jurnal Ilmiah Pendidikan Matematika), 6(1), 39. https://doi.org/10.25273/jipm.v6i1.1569

Yuwono, S. D. (2020). Profil Kondisi Stres Di Masa Pandemi Covid-19 Sebagai Dasar Intervensi Dalam Praktek Mikrokonseling. Ristekdik: Jurnal Bimbingan Dan Konseling, 5(1), 132-138. 